\title{
VOCA Regimen
}

National Cancer Institute

\section{Source}

National Cancer Institute. VOCA Regimen. NCI Thesaurus. Code C9588.

A chemotherapy regimen consisting of etoposide, vincristine, cyclophosphamide, and doxorubicin that may be used in the treatment of small cell lung cancer (SCLC). 